\title{
An Early Qing Claim of India as a Subject State ${ }^{1}$
}

\author{
MATTHEW W. MOSCA \\ University of Washington, Seattle
}

The Waiguo ji, a brief work by the early Qing official Zhang Yushu, lists India (Enetkek) among countries said to have submitted to the Qing state. According to Zhang, the submission of India, together with that of Tibet, derived from the decision of their overlord Güši Qaġan to become a tributary. This short article shows that Zhang's assertion derived from his work as an editor on two works concerning the Shunzhi emperor. It explores the basis of this claim, and discusses why it ceased to appear after the first two decades of the Kangxi reign.

\section{對清初「印度爲大清附屬國」一說的分析}

\begin{abstract}
MATTHEW W. MOSCA 馬世嘉
華盛頓大學歷史系

摘要

清官張玉書在清代初期短篇著作《外國紀》中對印度 (文中被稱爲「厄內五黑部落」) 有 所提及，且聲稱該政體在當時已經歸附於大清。在著作中張玉書表示，由於顧實汗進 貢清朝的決定, 其管轄的印度和西藏地區也成為了大清附屬國。本文將展示張玉書這 一觀點來源於他擔任兩篇有關順治帝的編輯任務的經歷。本文亦將剖析張玉書觀點 的根據，並探討爲何在康熙二十年後這一觀點便不在文獻中出現。
\end{abstract}

In a work composed in the late 1670s, the Qing official Zhang Yushu listed India, under its Manchu name Enetkek, among the polities that had submitted to the Qing state. A similar claim is found in a slightly earlier official text lauding the deceased Shunzhi Emperor. This short article offers a preliminary investigation of the origin of this claim, and the context of its emergence and disappearance. Zhang Yushu's effort to emphasize Qing political legitimacy by citing the specific geographical extent of its claims to domination had a pedigree going back to the time of Nurhaci. However, by the late Kangxi reign, changes in the Qing political conception of Inner Asia, coupled with a tightening of the evidential basis required to claim the subordination of other states, led to the disappearance of any suggestion of nominal Qing domination over India.

1. The author would like to thank Kicengge (Chengzhi), Luo Shengji, Hosung Shim, Gou Wu, and Sue Shuhui Zhou for their generous assistance, and also the anonymous reviewer for their useful feedback. He also thanks Mårten Söderblom Saarela and Eric Schluessel for their editorial corrections and improvements. 


\section{Zhang Yushu and the Waiguo ji}

In his short Waiguo ji 外國紀 (“Record of Foreign Countries”), Zhang Yushu² 張玉書 (1642-1711) enumerates tribes and countries that had ostensibly submitted or attached themselves ( $f u$ 附) to the early Qing state. ${ }^{3}$ These entities are grouped in sections divided chronologically by reign era, beginning with the Tianming era of Nurhaci and concluding in the early Kangxi era. Among the entities listed under the heading of the Tiancong era (1627-1636) is the Oyirad (Elude buluo 厄魯得部落, Ma. Ūlet), led by Güši Qagan (Ch. Gushi han 顧實汗, Ma. Gusi han). Zhang does not specify the year in which Güši Qagan submitted to the Qing. Following the entry for the Oyirad is one for Tibet (Tanggute buluo 湯古忒部落). A third entry under the name Tubote 圖白忒部落 merely notes that this is an alternative name for Tibet, reflecting the fact that two Mongolian names for Tibet, Tanggud and Töbed, along with their Manchu forms Tanggūt and Tubet, were used simultaneously in Qing records of this period. Finally, there is an entry for India under the name "tribe of Enetkek" (Eneitehei buluo 厄內忒黑部落), ${ }^{4}$ with an appended note explaining simply that this is "the extreme west, Great Western Heaven" (ji xi, Da Xitian 極西, 大西天). ${ }^{5}$ This statement implicitly contrasts India with Tibet, which Zhang described as the "Small Western Heaven" (Xiao Xitian 小西天). ${ }^{6}$

Zhang regarded both Tibet and India as subordinate to the Oyirad. The entry for Tanggud concludes with the note, "Tanggud, and India and Töbed are all subject to the Oyirad" (Tanggute ji Eneitehei Tubote ju Elude suoshu 湯古心及厄內心黑圖白忒俱厄魯得 所屬), explaining why all four are listed in sequence in his work. ${ }^{7}$ Moreover, both the entry for the Oyirad and that for Tibet describe the close relationship between the Dalai Lama and Güši Qaġan. Hence, while Zhang does not specify the moment when India ostensibly joined the list of states that had submitted to the Qing, it is implied that India submitted to the Qing indirectly via its putative overlord, Güši Qağan.

I have not found a document in which Güši Qaġan claimed to the Qing that he

2. Fang Chao-ying, "Chang Yü-shu" in Eminent Chinese of the Ch'ing Period, ed. Arthur W. Hummel (Washington, DC: United States Government Printing Office, 1943), vol. 1, 65-66.

3. The version of this work used in the present study is found in Jingiang Zhang Wenzhen gong (Yushu) wenji 京江張文貞公( 玉書)文集, in Jindai Zhongguo shiliao congkan xubian di qishiba ji 近代中國史料叢刊續編第七十八輯, ed. Shen Yunlong 沈 雲龍 (Taibei: Wenhai chubanshe, 1974), vol. 773, 799-828 (8.26a-40b). It was also reprinted in the Zhaodai congshu 昭 代叢書 (Xinji biebian bu 辛集別編補) in Congshu jicheng xubian, shi bu, dili lei, Zhong wai zaji zhi shu叢書集成續編. 史部. 地理類·中外雜記之屬, vol. 65 (Shanghai: Shanghai shudian, 1994), 871-77.

4. In this case the underlying Mongolian or Manchu name was likely not in the standard form Enedkeg or Enetkek. Zhang's Chinese transcription seems to resemble the form Enedke, attested in a Qing-era printed Buddhist text of 1650: See A. Róna-Tas, "The Mongolian Versions of the Thar-pa čhen-po in Budapest," in Mongolian Studies, ed. Louis Ligeti (Amsterdam: Verlag B. R. Grüner, 1970), 461.

5. As discussed below, Zhang's preface to the Waiguo ji specified the countries regarded as marking the extreme west (India/Enetkek), east (the dog- and reindeer-herding peoples), north (Qalqa), and south (Liuqiu) of Qing political influence. Here, in the main text, he indicates this status for all of these states except Liuqiu.

6. Zhang, Waiguo ji, 810-11 (8.31b-32a).

7. Zhang, Waiguo ji, 811 (8.32b). 
was ruler of India, or indeed had any connection to India whatsoever. However, the researches of Zahiruddin Ahmad indicate grounds on which he might conceivably have advanced such a claim. In his 1643 History of Tibet, the Fifth Dalai Lama Ngag-dbang blo-bzang rgya-mtsho (1617-1682) states that when Güši Qaġan was proclaimed king of Tibet in April, 1642, "the king of India" named Ra-kho Shing, together with "the king of Yam-Bu (Kathmandu) in Nepal; the king of mNa'-Ris and many other border-kings sent many products of their countries." Ahmad speculates that the name Ra-kho Shing "probably stands for Raghu Singh, who was, possibly, a petty king on the Indo-Tibetan border." In balance, we can conclude that Zhang Yushu believed there was evidence that Güši Qaġan claimed some form of political domination over India, but the nature of this evidence remains to be established.

\section{The Waiguo ji and its Sources}

Although Zhang's Waiguo ji is preserved as part of his collected writings and therefore is not an official Qing record, its composition was connected to his work as a literary official. Zhang took his jinshi degree in 1661 (Shunzhi 18), entered the Hanlin Academy, and then embarked on a long career that included serving as compiler for official works. ${ }^{10}$ Like other eminent literary officials of his time, Zhang had first been assigned to study Manchu in the Hanlin Academy. ${ }^{11}$ The preface to the Waiguo ji is undated, but the last date recorded in the work seems to be 1676 (Kangxi 15). ${ }^{12}$ It is thus a product of Zhang's early years of service, prior to his brief retirement in $1684 .^{13}$

How we link the content of the Waiguo ji to Zhang's career as an official editor depends in part on how we interpret the work. The body of the Waiguo ji is essentially an annotated list of all non-Chinese political entities that in Zhang's view had in some way submitted to the Qing court. If regarded as a work of geography, it can most obviously be linked to the first version of the Huangyu biao 皇輿表, a set of tables summarizing the political and administrative histories of different parts of the Qing realm. Zhang Yushu served among the general editors (zongcai guan 總裁官) of the first version

8. A History of Tibet by Nag-dBan Blo-bZain rGya-TSHo, Fifth Dalai Lama of Tibet, trans. Zahiruddin Ahmad (Bloomington: Indiana University Research Institute for Inner Asian Studies, 1995), 197. See also: Zahiruddin Ahmad, Sino-Tibetan Relations in the Seventeenth Century (Rome: Istituto Italiano per il Medio ed Estremo Oriente, 1976), 133.

9. Ahmad, History of Tibet, 312. Sum-pa mkhan-po, in his Annals of Kokonor, also records that gifts were presented to Güši Qagan from the "king of India" on this occasion. See: Ho-Chin Yang, The Annals of Kokonor (Bloomington: Indiana University Publications, 1969), 39. I am indebted to Hosung Shim for directing me to Sum-pa mkhan-po's work.

10. Fang, "Chang Yü-shu," 65-66.

11. QSL-KX, juan 3, Shunzhi 18/6/9. Note: QSL refers to Institute of History and Philology, Academia Sinica, Qing shilu 清 實錄, http://hanchi.ihp.sinica.edu.tw.

12. Zhang, Waiguo ji, 814 (8.33b).

13. Fang, "Chang Yü-shu," 65-66. 
of this work, which bears an imperial preface of July 4, 1679 (Kangxi 18/5/27). ${ }^{14}$ It is therefore possible that Zhang prepared the Waiguo $j i$ as part of his personal notes for this work. ${ }^{15}$ The trouble with this hypothesis, however, is that the first version of the Huangyu biao covered only those parts of the realm administered through the junxian 郡縣 form of bureaucratic territorial administration, that is, the provinces of China proper. Only the expanded version, finished in 1704, included territories in Inner Asia and tributary states. While it remains possible that the Waiguo ji was a byproduct of Zhang's research for the Huangyu biao, this cannot be conclusively established.

It is also possible to interpret the Waiguo ji not as a geographic work, but as a political text celebrating the achievements of early Qing rulers. This interpretation is supported by the content of Zhang's long preface to the work, which stressed the vast reach of Qing political influence. This preface contains an important clue concerning the intersection of Zhang's private writings and official career. His preface stated:

\section{東極于使鹿使犬, 西極於厄內忒黑, 土魯畨, 北極於喀爾喀, 俄羅斯, 南極于琉球, 暹 羅, 其為道里不可以數計, 而皆以德服而不以威取, 則自漢以來所未有也}

[Qing tributaries] extend in the east as far as those who herd deer and dogs, ${ }^{16}$ in the west as far as India [Enetkek] and Turfan, in the north as far as the Qalqa and Russia, and in the south as far as Liuqiu [Ryūkyū] and Siam. The route distances are beyond calculation, and all have submitted in response to imperial virtue and have not been obtained [as tributaries] by having been overawed by threat of force. This is unprecedented from Han times onward. ${ }^{17}$

Although the exact phrasing differs, the content of this passage closely parallels one found on the memorial stele prepared for the tomb of the Shunzhi emperor. The text of this stele, entered into the Veritable Records (Shilu 實錄) under the date February 22, 1668 (Kangxi 7/1/11), reads in part:

\section{德音則遐邇咸遍, 故使山陬海澨, 莫不覃被恩膏. 東至使鹿、使犬等國, 西至厄內忍 黑, 吐魯番等國, 北至喀爾喀, 俄羅斯等國, 南至琉球, 暹羅.}

14. Huangyu biao 皇舆表 (Yangzhou: Jiangsu Guangling guji keyinshe, 1991). The front matter lists Zhang as a "general editor of the first compilation in Kangxi 18” (康熙十八年初修總裁官).

15. In an earlier article I speculated that Zhang's Waiguo ji was perhaps a byproduct of his work on the Huangyu biao: Matthew W. Mosca, "The Literati Rewriting of China in the Qianlong-Jiaqing Transition," Late Imperial China 32, no. 2 (2011), 98-99.

16. Kicengge kindly informed me that these terms refer to the peoples termed buhū takūrara niyalma and indahūn takūrara niyalma in early Qing records (personal correspondence, February 26, 2020). On the Tungusic peoples likely indicated by these terms, see: Loretta E. Kim, Ethnic Chrysalis: China's Orochen People and the Legacy of Qing Borderland Administration (Cambridge, MA: Harvard University Asia Center, 2019).

17. Zhang, Waiguo ji, 801 (8.27a). 
His virtuous teachings reached everywhere, near and far, and therefore caused [those residing on] remote mountains and ocean shores to all feel the universal extent of his grace. In the east [his influence reached] to those countries that herd deer and dogs, in the west to the countries of India [Enetkek] and Turfan, in the north to the countries of Qalqa and Russia, in the south to Liuqiu and Siam. ${ }^{18}$

There is good reason to think that Zhang himself may have had a hand in drafting this commemorative text, because in 1667 (Kangxi 6) he had been assigned to the committee compiling the Veritable Records of the Shunzhi reign. ${ }^{19} \mathrm{He}$ was listed among the editors of these Veritable Records when they were presented to the throne in $1672 .{ }^{20}$ The final portion of those Veritable Records contains:

聲教所訖，東至使鹿、使犬，西至厄訥忒黑，吐魯番，北至喀爾喀，鄂羅斯，南至琉 球, 暹羅.

His fame and influence reached in the east to those who herd deer and dogs, in the west to India [Enetkek] and Turfan, in the north to Qalqa and Russia, and in the south to Liuqiu and Siam. ${ }^{21}$

Zhang must also have read extensively in Qing archives from the Tiancong and Chongde era as assistant chief editor for the Veritable Records of Hong Taiji, formally presented in 1682, a decade after their Shunzhi counterpart. ${ }^{22}$ After Zhang had lauded the farreaching influence of Nurhaci, Hong Taiji, and Shunzhi in his preface to the Waiguo ji, he added the following note:

今紀諸國及諸部落名目, 間據見聞以其事附紀于下.

I now record the names of these countries and tribes. Among them, based on what I have seen and heard, I have supplementally recorded their affairs below [the name of the country]. ${ }^{23}$

It seems, then, that Zhang's purpose in compiling the Waiguo ji was a mixture of geographic interest regarding foreign states and the intention-drawn from Qing imperial practice-of listing putative tributaries as a means of praising the political achieve-

18. QSL-KX, juan 25, Kangxi 7/1/11.

19. QSL-KX, juan 24, Kangxi 6/9/5.

20. QSL-SZ, front matter juan 2, jin shilu biao 進實錄表 (Kangxi 11/5/20).

21. QSL-SZ, juan 144, Shunzhi 18/1/7.

22. QSL-Taizong, front matter juan 2, jin shilu biao 進實錄表 (Kangxi 21/9/22).

23. Zhang, Waiguo ji, 801 (8.26a). 
ments and virtue of Qing rulers. Although we cannot conclusively link Zhang's decision to compile the Waiguo $j i$ to a specific official editorial project, there is no doubt that the contents of his work were drawn from Qing archival records.

Zhang's private Waiguo ji sheds light on a mysterious aspect of this official claim that Qing influence extended to India in the Shunzhi era. The other countries mentioned in Shunzhi's memorial stele can all be identified as having had some form of direct contact with the Qing court. In most cases, for instance with Turfan, Russia, Siam, and Liuqiu, their first contact with the Qing state occurred in the Shunzhi era. In this context, India (Enetkek) is a puzzling exception, since no document seems to record it having contact with the Qing in the Shunzhi era. Given that Zhang was one of the editors working on this memorial text, we can infer that it is based on the claim, only made explicit in Zhang's private Waiguo ji, that Güši Qagan's submission was regarded by the Qing state as entailing that of both Tibet and India.

\section{The Chronology of the Qing Claim}

Zhang lists the Oyirad, Tibet, and India among those entities that putatively submitted to the Qing in the Tiancong period, that is, prior to Hong Taiji's proclamation of the new Chongde era in 1636. However, according to Zhang's editorial principles, this simply indicates that the head of this political conglomeration, Güši Qagan, had first made contact with the Qing in that era. Zhang does not necessarily claim that it was in the Tiancong era that Güši Qan claimed India as his subject state. Moreover, we should not put too much faith in Zhang's dating, as his work contains chronological errors. ${ }^{24}$ Indeed, his dating of Qing-Oyirad contact to the Tiancong era itself appears to be wrong. The first passage in the Veritable Records referring to Güši Qaġan states that his envoy, regarded by the Qing as bearing tribute, arrived on November 27, 1637 (Chongde 2/10/12). This entry contains the line: "He sent his envoy in the bingzi year, but because the road was long, he only arrived in the present year" (zhi bingzi nian, nai qian shi, yin lu yuan, yu shi sui shi zhi 至丙子年, 乃遣使, 因路遠, 於是歲始至). ${ }^{25}$ It is conceivable that this line led Zhang to date Güši Qagian's submission to the bingzi year, 1636, which commenced in the Tiancong era but ended in the Chongde era. In all likelihood, however, Zhang mistakenly placed the Oyirad, Tibet, and India in the Tiancong era when he should, based on his editorial principles, have placed them in the following Chongde era.

24. To give one example, Zhang mistakenly records the Ordos (Eerduosi buluo 鄂爾多斯部落) as one of the first Mongol groups to submit to the Qing, placing this event under Nurhaci in the Tianming period. Zhang, Waiguo ji, 804-5 (juan 8, 28b-29a).

25. QSL-Taizong, juan 39, Chongde 2/10/12. 
Nurhaci, conscious of his humble beginnings, employed the rhetorical strategy of emphasizing his power by listing conquered or subordinate states and peoples. This was not mere boasting, but made the crucial point that his conquests proved that he enjoyed the favor of Heaven. When Ligdan Qagan attempted to overawe Nurhaci with the claim to rule all Mongols, he replied in 1620:

abka na gosifi, hadai gurun, hoifai gurun, ulai gurun, yehei gurun, fusi, niowanggiyaha, keyen, cilin, jakūn amba ba be, abka na minde buhe kai.

Heaven and Earth cherished me, and Heaven and Earth bestowed on me the states of Hada, Hoifa, Ula, and Yehe, and the [Ming outposts of] Fuxi, Qinghe, Kaiyuan and Tieling, these eight great places. ${ }^{26}$

This practice of listing conquered territories to demonstrate military success and thus legitimacy was inherited by his son Hong Taiji. Because Qing rulers were incentivized to promote the strongest plausible claims to far-flung domination, this practice allows us to search for earlier evidence of Zhang's claim to Qing dominion over India. It appears that we can rule out such a claim in the Tiancong era. A letter sent to the king of Korea from the highest officials and aristocrats serving Hong Taiji, dated to March 8, 1636 (Tiancong 10/2/2), reads in part:

tulergi gurun be uhe obume dahabufi, ama, jui be ujire, ahūn, deo be gosire gese, kesi erdemu geren i gūnin de acabufi, niyalmai mujilen be bahafi, wesihun dergi mederi de isitala, wasihūn tanggūt gurun de niketele, amasi amargi mederi de isitala, ba ba $i$ gurun gemu buyeme dahaha.

[Hong Taiji] united the outer countries and caused them to submit. Like a father nurturing his son, like an elder brother cherishing his younger brother, he has attuned his grace and virtue to fit the hopes of everyone, and has obtained the hearts of the people; reaching in the east to the eastern ocean, approaching in the west to Tibet, reaching in the north to the northern ocean, the countries of all places admired him and submitted. ${ }^{27}$

Since the Tiancong era would end only a few months later, it is clear that Hong Taiji did not claim at that time to have extended his power to India. Rather, he claimed only

26. Guang Lu 廣祿 and Li Xuezhi 李學智, eds., Qing Taizu chao lao Manwen yuandang 清太祖朝老滿文原檔 (Taibei: Institute of History and Philology, Academia Sinica, 1971), vol. 2 昌字, 197. I have changed their gosibi to gosifi.

27. Kanda Nobuo 神田信夫 et al., eds., Manbun rōtō 滿文老檔 [Tongki fuka sindaha hergen i dangse] (Tōkyō: Tōyō Bunko, 1962), vol. 6, 906. 
to have approached or neighbored Tibet, possibly because Qing forces had driven the fleeing Ligdan Qagan to "Tibet" (i.e., close to the northern edge of Amdo). ${ }^{28}$

Hong Taiji clearly did not claim India as a neighbor or tributary in early 1636 , but a passage from two years later is more ambiguous. On August 15, 1638 (Chongde 3/7/6), he stated to an envoy of the Qalqa Mongols:

niyalmai isinaha ba de, gese niyalma isinarakū doro bio,, julge dailiyoo, dai yuwan, aisin, ere ilan gurun i han se i dailaha yabuha fonde wasihūn enetkek gurun, wesihun solgo gurun, amasi sahaliyan ula, julesi mederi de isitala yabuhabi, tere inu gese niyalma, gese morin kai,

但爾所能至，我師豈有不能至者乎? 昔遼金元三國之主，當征戰時，西伐厄訥忒 黑, 東抵朝鮮, 北及黑龍江, 南至於海, 無遠弗屆. 朕今日正與相等也.

Is there any reason why a place that one person has reached will not be reached by a similar person? In olden times, when the rulers of the Liao, Yuan, and Jin states made war and went forth, they went in the west as far as India, in the east as far as Korea, in the north as far as the Amur River, and in the south as far as the sea. These [i.e., the Qing military] are also similar people, similar horses. ${ }^{29}$

Hong Taiji does not claim here that his forces had in fact campaigned to India or extended their influence over it; this was a statement of the potential rather than the actual reach of Qing power. As Hong Taiji likely knew, the Yuan shi, which he was then having translated into Manchu, recorded that Chinggis Khan had campaigned as far as India. ${ }^{30}$ Thus, while this appears to be the earliest Qing reference to India as the real or potential limit of Qing power, it cannot be read as a claim that India was a Qing subject state in 1638. Although it is tempting to suggest that this is the passage Zhang misinterpreted as an early claim to Qing power over India, no reference is made here to Güši Qaġan, whom Zhang described as the intermediary between the Qing and India.

Another pertinent passage is recorded in the Veritable Records under the date April 14, 1642 (Chongde 7/3/16). There Hong Taiji comments:

28. Ligdan Qaġan's flight toward "Tibet" (Tanggūt gurun) is recorded in the Jiu Manzhou dang on January 28, 1636 (Tiancong 9/12/21), only a few months before the reference to Tibet noted above. Kanda Nobuo 神田信夫, Matsumura Jun 松村潤, and Okada Hidehiro 岡田英弘, eds., Kyū Manshūtō 舊滿洲檔, vol. 2 (Tōkyō: Tōyō Bunko, 1975), 359.

29. The Manchu text is found in Chūgoku Daiichi Rekishi Tōankan zō Naikokushiin Manbun tōan yakuchū: Sūtoku ni, sannenbun 中国第一歴史档案館蔵内国史院満文档案訳註 : 崇徳二·三年分, ed. Kawachi Yoshihiro 河内良弘 (Kyōto: Shōkadō Shoten, 2010), 417. The Chinese text is in: QSL-Taizong, juan 42, Chongde 3/7/6. Mark Elliott translates this final line more idiomatically as "These men, these horses, are [capable of] the same." (Mark C. Elliott, "Whose Empire Shall It Be? Manchu Figurations of Historical Process in the Early Seventeenth Century," in Time, Temporality, and Imperial Transition: East Asia from Ming to Qing, ed. Lynn A. Struve [Honolulu: University of Hawai'i Press, 2005], 46.)

30. Yuan shi 元史 (Beijing: Zhonghua shuju, 1976), vol. 1, 23 (juan 1). 
朕蒙皇天眷顧，昔時金國所屬，盡為我有. 沿海一帶，自東北以迄西北，至使犬，使 鹿, 產黑狐黑貂等國, 及厄魯特國, 在在臣服. 元裔,朝鮮, 悉入版圖.

I have enjoyed the fond regard of Heaven. All that belonged formerly to the Jin state is now possessed by me. The regions along the coast, from the northeast to the northwest, extending to the countries who herd dogs and deer and who produce black fox and black sable [fur], as well as the Oyirad, have everywhere submitted to me. The descendants of the Yuan, and Korea, have all become our territory. ${ }^{31}$

Here Hong Taiji explicitly cites the Oyirad as his subjects, no doubt based on the 1637 arrival of the envoy bearing "tribute" from Güši Qaġan. However, he does not mention India, or even Tibet, as a subject state. Given his maximalist claims in this rhetorical context, the preponderance of evidence suggests that neither India nor Tibet were claimed as even nominally subordinate to the Qing prior to the Shunzhi era, although the Oyirad were regarded as having submitted in the Chongde era.

In balance, then, it seems that there are three possible hypotheses. One is that the editorial team working on the Veritable Records for the Shunzhi era simply misinterpreted a document and wrongly came to believe that Güši Qaġan was claiming some form of dominion over India. The official team wrote this claim into the 1668 memorial stele for the Shunzhi emperor, and Zhang Yushu, a member of this team, reiterated it in his private writings. Another possibility is that, during the intense tripartite correspondence during the early Shunzhi era between the Qing court, the Dalai Lama, and Güši Qaġan, there did emerge the assertion that Güši Qaġan not only held secular control of Tibet, but also was in some way the overlord of India. A third possibility is that it was the Dalai Lama or another figure in Tibet who claimed (or was misinterpreted to claim) some dominion over India, and that this was in turn attributed to Güši Qag̉an by the political logic that Tibet was also under his control.

\section{A Claim Vanishes}

Although Qing documents claimed some form of political influence over India in the late 1660s and early 1670s, and Zhang's Waiguo ji reiterated those claims in the late 1670s, this assertion soon vanished from the Kangxi era documentary record. In all likelihood, this was due to three changes: A disinclination to cite evidence of Qing might that relied on archives from before the Qing conquest of Beijing in 1644; more rigorous

31. QSL-Taizong, juan 59, Chongde 7/3/16. I am indebted to Kicengge for directing me to this citation. A similar claim that does not mention India was made a few months later: QSL-Taizong, juan 61, Chongde 7/6/3. 
standards of proof for claiming subject states; and an emerging reconceptualization of how Qing territory was to be described.

Zhang's Waiguo ji simply listed all non-Chinese tribes and countries said to be subject to the Qing, making no distinction between those parts of Inner Asia that had come under direct Qing control and other lands that were only indirectly claimed as subordinate states due to the putative presentation of tribute. By 1690, however, Qing geographic and administrative sources began to formalize this distinction. The Kangxi edition of the Collected Statutes (Huidian 會典), completed in 1690, was not a geographic work but did describe the Qing administrative apparatus for various territories. In the Huidian, the Oyirad were placed under the purview of the Lifanyuan, together with the forty-nine jasag-banners of Inner Mongolia, the Qalqa, and the lamas living in these Inner Asian territories subject to the Qing. The Board of Rites, by contrast, had jurisdiction over “the various Tibetan temples” (Xifan gesi 西番各寺) in the regions of greater Tibet. It also had jurisdiction over tributary countries, which were listed as Korea, Turfan, Liuqiu, Holland, Vietnam, Siam, and Portugal (Xiyang). ${ }^{32}$ The expanded Huangyu biao of 1703 contained a similar division, albeit expressed in different terms. Qing territories in Inner Asia were listed in the chapter on Shengjing, and included the Qalqa, Oyirad, and Hami. An appendix to the work gave a list of tributary states, notably Korea, Vietnam, Liuqiu, Siam, Xiyang, and Holland. ${ }^{33}$

Neither the Kangxi Huidian nor the Huangyu biao referred to India, but indirectly they indicate two important changes that made Zhang's Waiguo ji obsolete. First, although the Oyirad were considered to be a part of Inner Asia notionally subject to the Qing, this status did not extend to Tibet. Put another way, the putative submission of Güši Qaġan was no longer considered to have entailed Qing dominion over Tibet. Why this should be so is an issue too complex to discuss within the framework of this paper. However, drawing on the extensive scholarship on Tibetan history in the seventeenth century, a few brief points can be made. First, the relationship between Güši Qaġan and the Dalai Lama, and the question of Güši Qaġan's political status with regard to Tibet, was an intricate one that drew in part on Buddhist religious concepts. From one standpoint, Güši Qaġan could be regarded as the secular king, or khan, of Tibet. However, he ostensibly "donated" his conquered Tibetan territories to the Dalai Lama, becoming his patron and protector. Thus, Güši Qaġan could not be described without qualification either as the secular ruler of Tibet or as a subordinate of the

32. Kangxi huidian 康熙會典 in Da Qing wuchao huidian 大清五朝會典 (Beijing: Xianzhuang shuju, 2006), 973-89 (juan 72.1a-73.12a), 1865 (juan 144, 1a).

33. Huangyu biao. The editorial principles of this work state that the list of tributaries is not complete and includes only "great states" subject to the jurisdiction of the Board of Rites. 
Dalai Lama. ${ }^{34}$ Until the time of Güši Qagan's death in 1655, the Qing government maintained relations with both men simultaneously, generally receiving envoys from them at the same time and in return dispatching parallel correspondence addressed to each. ${ }^{35}$ Between 1642 and 1655, the Qing addressed Güši Qaġan as (šasin-i bariğci) nom-un qag்an or "dharma king who upholds the faith" (Tibetan: [bstan-'dzin] chosrgyal]. ${ }^{36}$ This suggests that Güši Qaġan's most prestigious identity after 1642 stemmed from his role as secular counterpart to the Dalai Lama. It was tacitly acknowledged by all parties that Qing relations with the Dalai Lama required his consent. The Qing state did not explicitly term Güši Qaġan the ruler of Tibet, but Zhang Yushu was not necessarily wrong to believe that the Qing state treated Güši Qaġan during his lifetime as the de facto secular ruler of Tibet.

However, even as Zhang Yushu was writing his work, the early interpretation of Güši Qaġan's political significance that he described was coming to appear increasingly archaic. After Güši Qaġan's death, his descendants no longer played a meaningful political role in the Tibetan context. ${ }^{37}$ Not only did the Dalai Lama emerge as the effective ruler of Tibet in secular as well as religious terms, but his visit to Beijing in 1652-53 came to be seen in retrospect as a foundational moment in Qing relations with Tibet, largely effacing Güši Qaġan's key role from historical memory. ${ }^{38}$ For Qing official compilations composed in the second half of the Kangxi reign, Tibet was not considered a region under Oyirad control. The 1690 Huidian and 1703 Huangyu biao implicitly recognized Tibet, which was accorded the status of a tributary state, to be distinct from the Oyirad, who were under a different bureaucratic jurisdiction. By analogy, it would no longer be possible to claim that India was subject to Güši Qaġan and had submitted to the Qing indirectly on that basis.

It is also worth noting that the list of claimed tributaries in these two works of 1690 and 1703 now included only states that had sent envoys to the Qing court and formally participated in rituals associated with the tributary system. This led to a much shorter

34. On the status of Güši Qagan relative to the Dalai Lama in the governance of Tibet, see: Peter Schwieger, The Dalai Lama and the Emperor of China: A Political History of the Tibetan Institutions of Reincarnation (New York: Columbia University Press, 2015), 50-61; Ishihama Yumiko, "The Dalai Lama as the cakravarti-rāja as Manifested by the Bodhisattva Avalokiteśvara,” Cahiers d'Extrême-Asie 24 (2015): 169-88.

35. The classic overview of Qing relations with Güši Qagan and the Dalai Lama in this period is Zahiruddin Ahmad, SinoTibetan Relations, 120-22, 154-87.

36. Cing ulus-un dotuġadu narin bicig-ün yamun-u Mongǵol dangsa ebkemel-ün emkidkel, (Kökeqota: Öbör Monggol-un arad-un keblel-ün qoriy-a, 2003), vol. 3, 252, 315.

37. On the later attempt of Lajang Qaġan to resume what he regarded as the patrimony of the Qošot Mongols in Tibet, established by Güši Qagan, see Luciano Petech, China and Tibet in the Early XVIIIth Century: History of the Establishment of Chinese Protectorate in Tibet (Leiden: Brill, 1972), 8-31.

38. It is also worth noting parenthetically that the emerging Qing rivalry with the Junghars, a branch of the Oyirad not directly descended from Güši Qagan, also tended retrospectively to erase the view of the Oyirad as a single group under a single leader. However, changing Qing political conceptions of the Oyirad from a single entity to a fragmented group fall outside the scope of this study. 
list of tributaries than Zhang had ventured, but one more strongly supported by documentary proof. Since no Indian ruler had at that point sent an envoy to the Qing court, this stricter delineation of tributaries would also have excluded a claim to India.

Finally, we can consider the Da Qing yitong zhi, the comprehensive gazetteer of the Qing realm. Although work had begun on this compilation in 1686, it was only finished in 1741. Its entry on Qinghai explained that Güši Qagan of the Oyirad had presented tribute at the start of the Qing period, but there is no suggestion that the scope of his submission extended beyond the Qinghai region. ${ }^{39}$ The section on Tibet explains that in 1642 (Chongde 7) the Dalai Lama had "sent an envoy and submitted" (qian shi guicheng 遣使歸誠), and in 1652 (Shunzhi 9) the Dalai Lama had "come to court" (laichao 來朝). ${ }^{40}$ No suggestion is made that Güši Qagan was the ruler of Tibet in his lifetime, or that his submission entailed that of Tibet. The Yitong zhi does refer to India, under its Manchu name Enetkek (Eneteke guo 厄昞特克國), but only as a neighbor of Tibet. ${ }^{41}$ No suggestion is made in the work that India was subordinate to the Qing. The list of tributaries in the Yitong zhi is fuller than those given in the Kangxi Huidian and Huangyu biao, because it included states that had contact with the Ming but not the Qing court. India, however, was not listed as a tributary. Simply put, Zhang's interpretation that Güši Qaġan's submission brought not only the Oyirad but also Tibet and India into subordination to the Qing vanished from later compilations.

An ironic coda to this story concerns a later iteration of India in the Qing geographic consciousness, under the name Hindustan. When Qianlong pondered whether to open direct political contact with Hindustan, his officials in Yarkand urged him to take the view that since Ahmad Shah Durrani had conquered Hindustan, the Afghan's putative tribute mission to the Qing court meant that Hindustan could also be regarded as having come under the Qing sway without the need for direct contact. In some later writings Qianlong does indeed claim Hindustan at a tributary, but does not clarify the basis for his claim. ${ }^{42}$ The circumstances of this vague claim to dominion over Hindustan via Ahmad Shah Durrani parallel those associated with the earlier claim to domination over Enetkek via Güši Qaġan.

39. Da Qing yitong zhi 大清一統志 (Beijing: Wuyingdian, 1751), Qinghai 3a. The section on Tibet notes that Güši Qaġan was requested to intervene in Tibet and left his son there as "khan," but this event is not portrayed as relevant to the political relationship of Tibet to the Qing (Xizang 2b).

40. Da Qing yitong zhi, Xizang 2a.

41. Da Qing yitong zhi, Xizang 7b.

42. Mosca, From Frontier Policy to Foreign Policy, 76-83. 


\section{Bibliography}

A History of Tibet by Nag-dBan Blo-bZan rGya-TSHo, Fifth Dalai Lama of Tibet, translated by Zahiruddin Ahmad. Bloomington: Indiana University Research Institute for Inner Asian Studies, 1995.

Ahmad, Zahiruddin. Sino-Tibetan Relations in the Seventeenth Century (Rome: Istituto Italiano per il Medio ed Estremo Oriente, 1970.

Cing ulus-un dotuġadu narin bicig-ün yamun-u Mongġol dangsa ebkemel-ün emkidkel. Kökeqota: Öbör Monggol-un arad-un keblel-ün qoriy-a, 2003.

Da Qing yitong zhi 大清一統志. Beijing: Wuyingdian, 1751.

Elliott, Mark C. "Whose Empire Shall It Be? Manchu Figurations of Historical Process in the Early Seventeenth Century." In Time, Temporality, and Imperial Transition: East Asia from Ming to Qing, edited by Lynn A. Struve, 31-72. Honolulu: University of Hawai'i Press, 2005.

Fang Chao-ying. "Chang Yü-shu." In Eminent Chinese of the Ch'ing Period, edited by Arthur W. Hummel, vol. 1, 65-66. Washington, DC: United States Government Printing Office, 1943.

Guang Lu 廣祿 and Li Xuezhi 李學智, eds. Qing Taizu chao lao Manwen yuandang 清太祖朝老滿文 原檔. 2 vols. Taibei: Institute of History and Philology, Academia Sinica, 1971.

Huangyu biao 皇輿表. Yangzhou: Jiangsu Guangling guji keyinshe, 1991.

Ishihama Yumiko. "The Dalai Lama as the cakravarti-rāja as Manifested by the Bodhisattva Avalokiteśvara." Cahiers d'Extrême-Asie 24 (2015): 169-88.

Kanda Nobuo 神田信夫 et al., eds. Manbun rōtō 滿文老檔 [Tongki fuka sindaha hergen i dangse]. 7 vols. Tōkyō: Tōyō Bunko, 1962.

Kanda Nobuo 神田信夫, Matsumura Jun 松村潤, and Okada Hidehiro 岡田英弘, eds. Kyū Manshūtō 舊滿洲檔. 10 vols. Tōkyō: Tōyō Bunko, 1975.

Kangxi huidian 康熙會典. Vols. 1-2 of Da Qing wuchao huidian 大清五朝會典. Beijing: Xianzhuang shuju, 2006.

Kawachi Yoshihiro 河内良弘, ed. and trans. Chūgoku Daiichi Rekishi Tōankan zō Naikokushiin Manbun tōan yakuchū: Sūtoku ni, sannenbun 中国第一歴史档案館蔵内国史院満文档案訳註: 崇徳二・ 三年分. Kyōto: Shōkadō Shoten, 2010.

Kim, Loretta E. Ethnic Chrysalis: China's Orochen People and the Legacy of Qing Borderland Administration. Cambridge, MA: Harvard University Asia Center, 2019.

Mosca, Matthew W. "The Literati Rewriting of China in the Qianlong-Jiaqing Transition." Late Imperial China 32, no. 2 (2011): 89-132.

- From Frontier Policy to Foreign Policy: The Question of India and the Transformation of Geopolitics in Qing China. Stanford: Stanford University Press, 2013.

Petech, Luciano. China and Tibet in the Early XVIIIth Century: History of the Establishment of Chinese Protectorate in Tibet. Leiden: Brill, 1972.

Róna-Tas, A. "The Mongolian Versions of the Thar-pa čhen-po in Budapest." In Mongolian Studies, edited by Louis Ligeti, 445-93. Amsterdam: Verlag B. R. Grüner, 1970.

Institute of History and Philology, Academia Sinica. Qing shilu 清實錄. http://hanchi.ihp.sinica. edu.tw.

Schwieger, Peter. The Dalai Lama and the Emperor of China: A Political History of the Tibetan Institutions of Reincarnation. New York: Columbia University Press, 2015.

Yang, Ho-Chin, ed. The Annals of Kokonor. Bloomington: Indiana University Publications, 1969.

Yuan shi 元史. Beijing: Zhonghua shuju, 1976.

Zhang Yushu. Jingiiang Zhang Wenzhen gong (Yushu) wenji 京江張文貞公(玉書)文集. In Jindai Zhongguo shiliao congkan xubian di qishiba ji 近代中國史料叢刊續編第七十八輯, edited by Shen Yunlong 沈雲龍, vol. 773, 799-828 (8.26a-40b). Taibei: Wenhai chubanshe, 1974. 
Zhaodai congshu 昭代叢書 (Xinji biebian bu 辛集別編補). Congshu jicheng xubian, shi bu, dili lei, Zhong wai zaji zhi shu叢書集成續編. 史部. 地理類・中外雜記之屬. Volume 65, 871-77. Shanghai: Shanghai shudian, 1994. 